\title{
CONCEPTUAL AND FUNCTIONAL DIVERSITY OF THE OMBUDSMAN INSTITUTION IN ASIA (COMPARATIVE CONSTITUTIONAL LAW ANALYSIS)
}

\author{
Lívia Trellová \\ Comenius University in Bratislava, Faculty of Law
}

\begin{abstract}
This paper deals with conceptual and functional diversity of the Ombudsman Institution in Asia from comparative constitutional point of view. The author analyses ombudsman institution in Asia. Characteristics and definiton of Ombudsman made by European legal doctrine and also by the International Bar Association resolution was used as an starting point to set certain criteria upon which Asian ombudsman institutions are subject to comparative anaysis. Finla part throws light on the prospects and problems of models, establishment and functioning of ombudsman institutions in Asia.
\end{abstract}

Key words: Parliamentary Ombudsman, Ombudsman definition, Asian Ombudsman systems and institutions

\section{INTRODUCTION}

The ombudsman institution has its origin in Sweden where the first Ombudsman Office (justitieombudsman as an ombudsman for justice) was established in 1809. The concept of the ombudsman has developed over the years in Sweden. At the present time according to the swedish constitution of 1974 there are four Parliamentary Ombudsmen (Riksdagens ombudsmän), one of whom is designated Chief Parliamentary Ombudsman. In addition to this, there may be one of more Deputy Ombudsmen. They are primarily established to supervise, to the stated extent, that those who exercise public authority are to obey the laws and other statutes and fulfil their obligations in other respects. But we have to mention that the mandate of the parliamentary ombudsmen has dual nature: supervising the rule of law in the public administration and the judiciary, and ensuring that fundamental rights and freedoms of the citizens are not encroached upon in public administration. ${ }^{1}$ Typical features of the Swedish classical model of ombudsman, as widely agreed, were described by Donald Rowat as follows: an independent and nonpartisan officer of the legislature, usually provided for in the constitution who supervises the administration; who deals with complaints from the public against administrative injustice and maladministration; and who has the power to investigate, criticise and publicise, but not to reverse administrative action. ${ }^{2}$

The idea of the ombudsman did not spread beyond Sweden until the early twentieth century when newly independent Finland incorporated ombudsman office in its 1919 Constitution. Considerably lately it was followed by adoption of little bit different version of ombudsman office in two

1 The Act with Instructions for the Parliamentary Ombudsmen (Lag [1986:765] med instruktion för Riksdagens ombudsmän - "JO-instruktionen") issued 13 November 1986, revised 1 September 2014 by SFS 2014:802. Available at: https://www.jo.se/en/About-JO/Legal-basis/Instructions/.

2 ROWAT, D.C. (ed.): The Ombudsman. Citizen's Defender, p. xxiv. 
other Scandinavian countries (Constitution of Danmark of 1953 and in Norway in 1962). Following this development has the concept of the public sector ombudsman gained its popularity and spread throughout the world in less than two hundred years. The ombudsman office was also increasingly established in other counties but it was not until the $1980 \mathrm{~s}$ that federal or national ombudsmen began to appear on the Asian landscape, and the offices established since have taken many different forms. The adaptation of the ombudsman concept has been based on the need of alternative complaint processes to the courts, as an public authority that plays an important role for for strengthening democratic governance, rule of law and civil society.

The office has a name unique to the country concerned. It is difficut to define ombudsman in precise term. The International Bar Association resolution of 1974 provided the following definition of Ombudsman : An office provided for by the constitution or by action of the legislature or parliament and headed by an independent high-level public official who is responsible to the legislature or parliament, who receives complaints from aggrieved persons against government agencies, officials and employees or who acts on his own motion, and who has the power to investigate, recommend corrective action, and issue reports. ${ }^{3}$ Main functions and primary tasks that could be assigned to ombudsman office in general are: to investigate complaints from members of the public against public authorities, or initiate own-motion investigations; where complaints are found to be justified to secure or recommend redress for aggrieved persons; and to recommend improvements in systems, working practices and administrative procedures generally; or, if there are no systems, to recommend that there should be, in order to minimise the risk if the same mistakes being repeated. ${ }^{4}$ The ombudsman must be impartial and independent, but same way is characterised by accountability, an attribute that takes number of forms. An ombudsman as a public body performing public functions with public money must clearly be accoutable to the law by means of judicial review. He must also be held accountable to the people (both directly and through their elected representatives), by the means of its published reports, for the exercise of its powers and for the efficient and effective use of the resources allocated to the office.

There have been various adaptations of the legislative ombudsman around the world at he national and sub-national levels of government. Over the past few decades, the ombudsman concept has been expanded into other areas, in both public and private sectors, and even into the international or supranational level of governance. Public and private sectors institutions have seen the ombudsman mechanism- which is free of charge, accessible, informal and relatively fast compared to the courts - as a way of resolving disputes effectively and efficiently. The ombudsman is also seen as an means to offset the inequalities of size and bargaining power between large organizations and individulas with complaints. In this respect, the many uses of the ombudsman mechanism are forms of alternative dispute resolution. ${ }^{5}$

\section{CONCEPTUAL FRAMEWORK : OMBUDSMAN INSTITUTIONS IN ASIA}

As it was already mentioned ombudsman institutions arrived relatively late in Asia. Historically in a first phase formation of Asian grievance redress institutions of different origins took place in

\footnotetext{
3 Quoted in HOSSAIN, K., BESSELINK, L., SELASSIE, H., VÖLKER, E. (eds.): Human Rights Commissions and Ombudsman Offices: National Experiences throught the World, p. 642.

4 GREGORY, R., GIDDINGS, P. (eds.): Righting Wrongs. The Ombudsman in Six Continents, p. 5.

5 REIF, L.C. The Ombudsman, Good Governance and the International Human Rights System. p. 25.
} 
1940 s and early 1950 s by Communist governments in the People' s Republic of China (hereinafter: China) and Vietnam. These states established systems of internal supervision (within the executive branch), concretely the People's Supervisory Commision (later Ministry of Supervision) in China and the Special Inspection Board (later Government Inspectorate) in Vietnam. In the late $1960 \mathrm{~s}$ and 1970 s certain non-Communist governments went on to establish internal mechanisms of grievance redress, e.g. Japan (The Administrative Inspection Bureau), Malaysia (the Public Complaints Bureau). Third phase with its beginning in the early $1970 \mathrm{~s}$ and continues until present day. In this period much more independent institutions explicitly referenced existing ombudsman traditions were created.

First ombudsman office was established in the Indian province of Maharashtra in $1972^{6}$, but there is no uniform structure of the Lokayukta system. India also does not have a federal ombudsman. India was followed by many countries in the region that had adopted similar intitutions and minority of them incorporated it also into its constitutions. The first country which named an institution explicitly as ombudsman was Bangladesh in 1980 (however the institution was never established). Sri Lanka adapted Parliamentary Commissioner for Administration in 1981.

Pakistan was the first to adopt the classical ombudsman model at federal level. Against the backdrop of the court system being the only avenue open to the general public for seeking relief against the excesses by public agencies in administrative matters, and recognizing the difficulties faced by the citizen in going through the elaborate and expensive court process, the Pakistan government decided to set up the Office of the Wafaqi Mohtasib. This office would work as an administrative justice forum to deal with citizens' complaints and provide complainants with a quick and cheap alternative for the redress of their grievances. Pakistan's Interim Constitution of 1972 first provided for the appointment of a federal ombudsman as well as provincial ombudsmen. But it was not until 1983 that the Office of the Wafaqi Mohtasib started functioning. Provincial ombudsmen have also been appointed in three of the four provinces, in Balochistan, Sindh and Punjab, as well as in Azad Jammu and Kashmir. Other countries and jurisdictions followed suit. In 1988, Philippines established its Ombudsman Office. This was followed by Hong Kong (1989), South Korea (1994), Thailand (2000) and Indonesia (2000). ${ }^{7}$ From the relatively newer ombudsman institutions it is worth mentiong establishment of Jordanian Ombudsman Bureau in 2009 and two Bahraini institutions in 2012 (Inspector General Office - National Security Agency; Ombudsman for the Ministry of Interior). ${ }^{8}$

Asian continent is characterised by many historical, cultural, religious and political differences. All these differences cause ombudsman-like institutions differ significantly from the concept of the parliamentary ombudsman prevailing in European states. Despite all this many of ombudsman institutions and similar public grievance redress systems in Asia incorporate typical features of the internationally renowned ombudsman concept. On the other hand, there are numbers of institutions that are only partly comporting with traditional ombudsman concept and definitions, sometimes they can be more generally referred to as „administrative grievance redress mechanisms“.

6 In India, the Administrative Reforms Commission in its interim report from October 1966 suggested to the Government of India to establish the institution similar to Ombudsman (Lokpal in the Centre and Lokayukta in the States). Various abortive attempts were made from 1968 to 1989 to establish the institution of Lokal in the Centre by introducing different Bills in the Parliament. No Bill became an Act due to different reasons and that is the why no institution of Lokpal could be created at the Centre. On the other hand there was different approach towards formation of Lokayukta system.

7 TAI A. Diversity of Ombudsmen in Asia. In IOI Stockholm conference: 29. Back to Roots : Tracing the Swedish Origin of Ombudsman Institutions. Available at: http://www.theioi.org/publications/stockholm-2009-conference-papers.

8 International Ombudsman Institute (IOI) at: http://www.theioi.org/ioi-members\#anchor-index-1690. 
However mandates and powers of ombudsman-like institutions vary from country to country, we have chosen certain criteria upon which ombudsman-like institutions are to be compared (mainly criteria regarding the institutional structure, legal basis, independence and impartiality and powers of institutions).

The criteria mentioned are those that can be derived from the IOI Constitution criteria for institutional membership. ${ }^{9}$ These criteria describe the following characteristics of ombudsmen: They are created by law (or constitution), protect against named acts by public authorities, are independent of public authorities especially those over which they have jurisdiction, have the power to investigate complaints and make recommendations, are accountable through public reports to appropriate authorities, and have one or more incumbents appointed by the legislative body who can be removed only for cause. ${ }^{10}$

\subsection{Legal Basis}

Only a minority of institutions on the national level- and none on the regional level-is embodied in the respective national constitution. These include the Offices of the Ombudsman in Philipines, Thailand and Bangladesh ${ }^{11}$, the Provedor for Human Rights and Justice in Timor-Leste, the Parliamentary Commissioner for Administration in Sri Lanka, the Commission Against Corruption in the Special Administrative Region of Macao in China (hereinafter: Macao) and the General Inspection Organization in Iran. Most institutions on the national and regional level were estabished by

9 A public institution whether titled Ombudsman, People's Defender, Parliamentary Commissioner, Mediator, Human Rights Commission, Public Complaints Commission, Inspector General of Government, Public Protector or like designation, shall be eligible to become an Institutional member provided it exercises fully the following functions and meets the following criteria: (Article 2 Purpose and Principles, 2 of IOI Constitution):

a) it should be provided for by a Country, State, Regional or Local Constitution and/or an Act of a Legislature, or by international treaty,

b) its role should be to seek to protect any person or body of persons against maladministration, violation of rights, unfairness, abuse, corruption, or any injustice caused by a public authority, or official acting or appearing to act in a public capacity, or officials of a body providing devolved, partially or fully privatized public services or services outsourced from a government entity, and which could also function as an alternative dispute resolution mechanism,

c) it should operate in a climate of confidentiality and impartiality to the extent its governing legislation mandates, but should otherwise encourage free and frank exchanges designed to promote open government,

d) it should not receive any direction from any public authority which would compromise its independence and should perform its functions independently of any public authority over which jurisdiction is held,

e) it should have the necessary powers and means to investigate complaints by any person or body of persons who considers that an act done or omitted, or any decision, advice or recommendation made by any public authority within its jurisdiction has resulted in the kind of action specified in paragraph 2 (b),

f) it should have the power to make recommendations in order to remedy or prevent any of the conduct described in paragraph 2 (b) and, where appropriate, to propose administrative or legislative reforms for better governance,

g) it should be held accountable by reporting publicly to a Legislature, or other elected body, and by the publication of an annual or other periodic report,

h) its incumbent or incumbents should be elected or appointed by a Legislature or other elected body, or with its approval for a defined period of time in accordance with the relevant legislation or Constitution,

i) its incumbent or incumbents should only be dismissed by a Legislature or other elected body or with its approval for cause as provided by the relevant legislation or Constitution, and

j) it should have adequate funding to fulfill its functions.

10 GOTTEHRER, D. Fundamental Elements of An Effective Ombudsman Institution. In: IOI Stockholm conference: Plenary Session II: Developing the Working Methods and Tools of the Ombudsman. Available at: http://www.theioi.org/ publications/stockholm-2009-conference-papers.

11 Institution not yet established. 
a simple act of the legislature (Bahrain, China, Indonesia, Japan, Jordan, South Korea). Some are even based on a mere regulation, decree or ordinance ${ }^{12}$ (e.g. certain Pakistani institutions, Chinathe State Bureau for Letters and Calls, Malaysia, Vietnam).

\subsection{Appointment of Incumbent Officers and Term of the Office}

Contraty to the Swedish ombudsman model, heads of the ombudsman institutions are almost exclusively appointed by an executive authority. This is very similar to so called „executive ombudsman“ or „quasi-ombudsman“ as are known in Europe, both are public sector ombudsmen appointed and responsible to the executive power, but still independent in law and practice (e.g. UK, France). In Asia the appointing authority is predominantly head of state, or its equivalent (the King, the President), the (head of) government (the Chief Executive), or another representative of the executive branch on the national or regional level.

Some states have the ambition to make the appointment process more transparent and open so other branches of government (legislature, judiciary) or special councils may additionally be involved. In Thailand Ombudsmen (the Ombudsman Office comprises three Ombudsmen - the Chief Ombudsman and two other Ombudsmen) are appointed by the King of the Thailand, by that time appointment is countersigned by a Minister and National Legislative Assembly providing advice. In accordance with Constitution of 2007 appointments follow a selection procedure- a recommendation by a Selection Committee is required. ${ }^{13}$ In Hong Kong ${ }^{14}$, the Ombudsman is appointed by the Chief Executive after an open recruitment exercise which is locally advertised and organized by an executive search firm. The application and selection process is overseen by a Selection Committee comprised of two unofficial members of the Executive Council, the Chairman of the Public Service Commission, and the Director of Administration. ${ }^{15}$

At least three states do not state the dominant role of the executive in appointing process of ombudsman (e.g. Indonesia, Timor-Leste, Iran). In Indonesia and Timor-Leste, the Ombudsman is elected by the legislature, the former being chosen from a selection of candidates nominated by the President. In Iran, the judicial branch appoints the President of the General Inspection Organization. ${ }^{16}$

The Ombudsman is generally appointed for a fixed term of office set by legislation. Terms may vary from three years (South Korea), four years (Jordan, Pakistan), five years (Bahrain, China, India), six years (Thailand), seven years (Phillipines) or exceptionally eight years. In certain cases the term of the office is not stipulated but is limited by reaching age limit.

12 KRIEBAUM, U., KUCSKO-STADLMAYER, G. (eds.) Asian Ombudsman Institutions. A comparative legal analysis, p. 9.

13 The Selection Committee comprises the President of the Supreme Court of Justice, The President of the Constitutional Court, the President of the Supreme Administrative Court, the President of National Legislative Assembly (previously the President of the House of Representatives and the Leader of the Opposition).

14 Hong Kong is not a sovereign state, but is an integral part of China, in a form of special administrative territory. However, in the context of One country- Two systems policy (one for Hong Kong and the other for the rest of China) that underlies Hong Kong's Constitution, so Hong Kong's Ombudsman can be deemed as a national Ombudsman (not only for the purpose of this paper, the same approach is set out in e.g. GREGORY, R., GIDDINGS, P. (eds.) Righting Wrongs. The Ombudsman in Six Continents. p. 75; LO, S.S. Hong Kong's Indigenous Democracy: Origins, Evolution and Contentions. 2015

15 TAI A. Diversity of Ombudsmen in Asia. In IOI Stockholm conference: 29. Back to Roots : Tracing the Swedish Origin of Ombudsman Institutions. Available at: http://www.theioi.org/publications/stockholm-2009-conference-papers.

16 KRIEBAUM, U., KUCSKO-STADLMAYER, G. (eds.) Asian Ombudsman Institutions. A comparative legal analysis. p. 10. 
Another very important question determined by the term of the office is the possibility of removal from the office. Generally could be stated that ombudsman may be removed from office before the expiry of the term by an executive authority (the head of state, the head of the governement or another representative of the executive branch $)^{17}$ or special councils may be involved in this procedure as well. In removing the ombudsmen, relevant bodies are subject to different levels of preconditions and must observe more or less stringent procedures. Reasons that might serve as justification for removal are as follows: loss of confidence, loss of eligibility, physical or mental incapacity, criminal conviction, misbehaviour or failure to carry out the intended functions, misconduct, loss of citizenship, absence, insolvency or incompatibilities with the position. ${ }^{18}$

\subsection{Independence and impartiality}

There is an continuing debate over whether executive ombudsmen meet the definition of a classical ombudsman as it can be argued that their ability to act with independence is brought into question by reason of the fact that they have the task of investigating administrative arm of the government body which has appointed them. ${ }^{19}$ On the contrary an ombudsman who acts as an officer of a legislative body and is independent of the organizations reviewed is more difficult for others to control. Independence is strengthened when the Ombudsman is appointed or confirmed preferably by a supermajority of all members of a legislative body or entity other than those the ombudsman reviews. The best processes prevent political appointments.

The independence question is so actual in Asia because it is noteworthy that some Asian ombudsman and ombudsman-like institutions are explicitly declared to be independent (e.g. Bahrain, Indonesia, Malaysia, Jordan, Macao, Philipinnes, Thailand, South Korea) while others are not. The relation between ombudsman and executive branch is highly relevant because its main role is to investigate the public administration. In this context, at the beginning there was need for creation of an independent machinery falling outside the control of administration, and also for the protection of the human rights of the people.

However, of higher relevance could be regarded existence of institutional safeguards for the institutions' independence. A fixed, long term of office providing for reappointment and allowing for removal of the ombudsman only for cause (and preferably by a supermajority of the appointing entity) can be viewed as certian independence safeguards. So it coud be said, most ombudsmen enjoy remuneration safeguards; they cannot be removed except for cause and even then, it can only be done with the endorsement of Parliament or its equivalent. Financial well-being is another indication of institutional independence.

Another overriding essential feature which should not be avoided in this context is impartiality and fairness of ombudsman. Independence and impartiality are clearly of fundamental importance to the success of ombudsman work. The role of the ombudsman is to carry out impartial and

17 By the Head of state: Pakistan, Bahrain, Bangladesh, China, Thailand, Sri Lanka, Vietnam, South Korea; by the head of the governement : Malaysia, Macao, Jordan; or by another representative of the executive branch: India, Japan, China...

18 KRIEBAUM, U., KUCSKO-STADLMAYER, G. (eds.) Asian Ombudsman Institutions. A comparative legal analysis, p. 31.

19 E.g. GREGORY, R. Building an Ombudsman Scheme: Statutory Provisons and Operating Practices. In International Ombudsman Anthology, pp. 134-136; also REIF, L.C. The Ombudsman, Good Governance and the International Human Rights System, pp. 14-15. 
objective investigations into complaints and the official action to which they relate. At the end of the investigatory process the ombudsman must adjudicate impartially upon the facts disclosed by his investigation without making any presumption in favour of either person or department. As it was already described ombudsman should be in position to make findings and recommendations without fear or favour, and without regard to the consequences for himself or his office. ${ }^{20}$ And the ombudsman will be able to act in this manner only when he is independent.

\subsection{Powers of the Institution}

Ombudsman institution, in general, has been given extensive powers to investigate complaints. The institutions should protect citizens against injustices committed by government officialls, administration. The powers of ombudsman differ significantly from one Asian state to another. Moreover, an important distinction is also between the powers as institution enjoys during the course of investigation, in particular which instruments it is offered to collect the evidence, and the powers an institution enjoys following the conclusion of an investigation.

Investigatory powers of ombudsman could be divided into following areas (in this order it is searched): obligation to assist, enforcement of duty of assistance, interrogation of functionaries and other persons, acess to places of detention and other (governmental) premises. An area of powers after the conclusion of investigation involve recommendations, enforcement of the findings and the recommendations of the institution, annual reports, special reports.

Ombudsman usually investigate conduct of administrative bodies or public authorities, public servants. Thus, effective and correct taking of evidence requires certain assistance by the administration. The public administrations have obligation to assist their respective ombudsman during the investigation procedure and this is laid down by almost all jurisdicitons in Asia. Certain differences are whether this obligation is either unlimited ${ }^{21}$, or exist certain exceptions regarding secret and / or confidential information. Although it may seem complying with the ombudsman concept, the effectiveness of such prescribed obligation depend on whether compliance is based on the goodwill of the administration, or the ombudsman is granted instruments for its enforcement.

A large number of institutions, in particular in South Asia, have the power of compulsory interrogation. Some institutions may utilize police in that regard, or have the general power to issue arrest warrants. In cases where public servants fail to assist institutions, several jurisdictions foresee disciplinary proceedings against relevant public servant. ${ }^{22}$ While some institutions may only refer the matter to a superior authority, others may institute proceedings themselves. Indonesia and Thailand are examples of states where institutions report to a superior authority, while the institutions in Iran and the Philippines, may recommend the suspension of a public servant during an investigation. Additionally, Thailand and Sri Lanka protect confidentiality of proceedings by penalizing the disclosure of information obtained during investigations. ${ }^{23}$ Ombudsman institutions are often granted a general right to enter and search (governmental) premises, but in

20 GREGORY, R. Building an Ombudsman Scheme: Statutory Provisions and Operating Practices In REIF, L.: The International Ombudsman Anthology: Selected Writings from the Internatonal Ombudsman Institute, p. 139.

21 Bahrain, Indonesia, China, Japan, Jordan, Macao, Malaysia, Phillipines, South Korea, Sri Lanka, Thailand, Vietnam.

22 China, Indonesia, Jordan, Iran, Macao, Philippines, South Korea, Vietnam.

23 KRIEBAUM, U., KUCSKO-STADLMAYER, G. (eds.) Asian Ombudsman Institutions. A comparative legal analysis, p. 46. 
prevailing number of jurisdictions explicit permit legal basis is missing (exceptions are e.g. Bahrain, Timor-Leste).

Essential power of ombudsman should be to issue (usually not legally binding) recommendations to the public administrations following the investigation. These recommendations may address issues raised in the underlying complaint itself, or relate to systematic issues of maladministration. Many Asian ombudsmen are not explicitly granted a right to provide recommendations, they merely issue case reports, addressed to a competent official or the subject of the complaint. This predominant concept when ombudsman is required to address his recommendation to the body concerned or subject to the complaint, when some are directed towards superior authorities or others to both, could be regarded as sufficient when it has legal manifestation. Concerning enforcement of recommendations and findings, various mechanisms are employed to facilitate compliance (e.g. disciplinary proceedings against a public servant...). In many states where recommendations and findings are declared as not binding, bodies may be subject to an obligation to react (requiring notification on actions taken, or reasons for filing to do so) in stated time period. An Indonesian ombudsman may additionally monitor implementation of his recommendations through on-site inspection.

Other typical ombudsman task to publish annual report on ombudsman activities is required by almost all ombudsman institutions in Asia. Ombudsman should in annual report give an overview peformed over the course of preceding year, statistical data on cases disposed of and selected or general recommendations to the administration. Most of the ombudsman have to submit their annual report to an executive authority ${ }^{24}$, which itself is then often required to forward such reports to the legislature directly. Only few institutions are not required to submit annual report at all. ${ }^{25}$ Some ombudsman are also obliged to provide Head of State, Ministry of Interior or Governor of Province with special reports, regarding individual cases, in addition to their annual reports. ${ }^{26}$

\section{CONCLUSION}

Asia is endowed with a rich variety of legal and constitutional systems. For that reason there are bound to be significant differences of detail between Asian ombudsman schemes. A meaningful comparison of the multitude of Asian ombudsman concepts and institutions is difficult, not only because of diversity of legal systems, but also because of paucity of information on these systems. It was therefore set to limit this paper to general comparative overview based on analysis by given criteria. My main aim was to mention typical characteristics of ombudsman concept as it is decribed in the European and American point of view. In relation to these features I tried to present examples of Asian states where they are regulated or not.

Adopting a comparative approach, I have attempted to show the variety of schemes and models of ombudsman concept as it is regulated in states in Asia. The ombudsman is considered to be institution responsible for ensuring the quality of the implementation of government responsibilities in relation to the individual citizen, or through which the individual can seek redress. The ombudsman is instrument to encourage dialogue between the state (public authorities) and its citizens.

4 Bahrain, China, India, Pakistan, Sri Lanka, Vietnam.

25 Iran, Japan, Malaysia.

26 Bahrain, China, India. 
An ombudsman in terms of utility means „watchdog of the administration“ or „public safety valve“. It should be an institution which leads to an open government by providing a democratic control mechanism over the powers of the government The Ombudsmen described earlier function in government to receive and investigate complaints, among other responsibilities. The irreducible minimum characteristics such an Ombudsman must have are four: Independence; Impartiality and Fairness; Credible Review Process and Confidentiality.

In my point of view many Asian institutions called "Ombudsman" lacke one or more of the essential characteristics. Even from a brief glance, it becomes obvious that Asian institutions differ significantly from the European concept of parliamentary Ombudsman. While several states have embraced fundamental ideas of the Europen ombudsman concept, their implementation varies considerably.

The most significant distinguishing factor between Europen ombudsman concept and ombudsman institutions in Asia is certainly the affiliation within State powers. Traditional parliamentary ombudsman concept is based on idea that he is an officer of legislature, i.e. parliament. The only Asian institution that appears to be in line with European parliamentary ombudsman model and pursuant to International Bar Association's definition is the Provedor for Human Rights and Justice in Democratic Republic Timor-Leste. It was established under Section 27 of the Constitution of Timor-Leste in May 2002 and first opened its doors in 2006. He has a dual mandate covering human rights and good governance. ${ }^{27}$ The Provedor is a high-level public official that is appointed and removed by the parliament. It is responsible and reports to the legislature, which it may provide with recommendations concerning legislative measures. Human rights are very important part of his mandate and his scope of supervision.

The Office of the Ombudsman in Indonesia nad Phillipines are simlar to this model. The former's head is elected by the legislature, yet the executive branch possesses power of removal. In the Philippines, it is the other way around. Both issue reports and recommendations to the respective parliaments, while human rights are not within their purview. ${ }^{28}$

In many countries, especially those with a longer democratic tradition, the existence of ombudsman has helped focus attention on the need for adequate internal complaints procedures within the governement. That is the reason which probably inspired Asian contries to establish this kind of institution. I have to state that Asian ombudsman institutions appear to have closer ties with administrative organs than the respective legislature. Absence of relationship with legislature could be seen in weak constitutional and legislative safeguards to ensure the independence of investigation. If we omit varying degrees of independence of these institutions, it could be pointed out that Asian ombudsman institutions pursue quite similar objectives as European parliamentary ombudsman. Namely it can be redress of administrative grievances and also good governance. Fight against corruption is also often part of their agenda. All in all Asian ombudsman institutions must be viewed not only in legal but also in political context within their respective national systems.

27 More details available at: https://en.wikipedia.org/wiki/Office_of_the_Provedor_for_Human_Rights_and_Justice_ (Timor_Leste)

28 KRIEBAUM, U., KUCSKO-STADLMAYER, G. (eds.) Asian Ombudsman Institutions. A comparative legal analysis. p. 59 


\section{Bibliography:}

CIBULKA, L. a kol. Štátoveda. Bratislava: Wolters Kluwer, 2017.

GOTTEHRER, D.: Fundamental Elements of An Effective Ombudsman Institution. In IOI Stockholm conference: Plenary Session II: Developing the Working Methods and Tools of the Ombudsman. Available at: http://www. theioi.org/publications/stockholm-2009-conference-papers.

GREGORY, R., GIDDINGS, P. (eds.) Righting Wrongs. The Ombudsman in Six Continents. The Netherlands: IOS Press, 2000.

GREGORY, R. Building an Ombudsman Scheme: Statutory Provisons and Operating Practices. In: International Ombudsman Anthology.

HOSSAIN, K., BESSELINK, L., SELASSIE, H., VÖLKER, E. (eds.) Human Rights Commissions and Ombudsman Offices: National Experiences throught the World. The Hague: Kluwer Law International, 2000.

KRIEBAUM, U., KUCSKO-STADLMAYER, G. (eds.) Asian Ombudsman Institutions. A comparative legal analysis. Wien: Verlag Österreich, 2016.

REIF, L.C. The Ombudsman, Good Governance and the International Human Rights System. Leiden: Koninklijke Brill NV, 2004.

ROWAT, D.C. (ed.): The Ombudsman. Citizen's Defender. London: Allen and Unwin, $2^{\text {nd }}$ edition, 1968.

TAI A.: Diversity of Ombudsmen in Asia. In: IOI Stockholm conference: 29. Back to Roots : Tracing the Swedish Origin of Ombudsman Institutions. Available at: http://www.theioi.org/publications/stockholm-2009-conferencepapers.

\section{Contact information:}

JUDr. Lívia Trellová, PhD.

livia.trellova@flaw.uniba.sk

Comenius University in Bratislava, Faculty of Law

Šafárikovo nám. č. 6

P. O. BOX 313

81000 Bratislava

Slovak Republic 